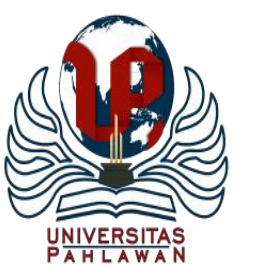

JURNAL BASICEDU

Volume 5 Nomor 2 Tahun 2021 Halaman 1027 - 1038

Research \& Learning in Elementary Education

https://jbasic.org/index.php/basicedu

\title{
Pengembangan Game Edukasi Berbasis Android untuk Meningkatkan Hasil Belajar Siswa di Sekolah Dasar
}

\author{
Ririn Windawati ${ }^{1}$, Henny Dewi Koeswanti² \\ Universitas Kristen Satya Wacana, Jawa Tengah, Indonesia ${ }^{1,2}$ \\ E-mail : $292017008 @$ student.uksw.edu $^{1}, \underline{\text { Henny.Koeswanti@uksw.edu }}^{2}$
}

\begin{abstract}
Abstrak
Media pembelajaran adalah alat bantu guru untuk menyampaikan informasi dalam kegiatan pembelajaran. Namun saat ini masih banyak Sekolah Dasar yang melaksanakan kegiatan pembelajaran hanya menggunakan media dalam bentuk audio visual, alat peraga, dan benda-benda di sekitar saja sehingga membuat siswa mudah bosan saat mengikuti kegiatan pembelajaran. Dengan adanya teknologi dapat dijadikan media pembelajaran yang menarik berupa game edukasi berbasis android. Tujuan dari penelitian ini yaitu mengetahui tingkat validitas menurut pendapat ahli mengenai produk pengembangan Game Edukasi Berbasis Android Untuk Meningkatkan Hasil Belajar Pada Siswa Kelas IV. Jenis penelitian ini adalah pengembangan atau Research and Development (R\&D). Penelitian dilaksanakan dengan menggunakan model desain pengembangan ASSURE yaitu Analisis Siswa (Analisis Learner), Menetapkan Tujuan (State Objektive), Memilih metode, media dan Materials (Select Method, Media \& Materials), Memanfaatkan Media dan Bahan ajar (Utizile media \& Materials), Melibatkan siswa dalam kegiatan pembelajaran (Require Learner),dan Evaluasi dan revisi (Evaluasi \& Revise). Data hasil uji validasi ahli diperoleh sebagai berikut: (1) persentase yang diperoleh dari uji validasi ahli materi sebesar $73 \%$ dengan kriteria penilaian yang didapatkan adalah tinggi; (2) presentase yang diperoleh dari uji validasi ahli media sebesar 97\% dengan kriteria penilaian yang didapatkan adalah sangat tinggi. Berdasarkan uji validasi dari ahli media dan ahli materi, dapat disimpulkan bahwa media pembelajaran berupa Game Edukasi Berbasis Android Untuk Meningkatkan Hasil Belajar Tema 7 Pada Siswa Kelas IV dapat dikatakan layak digunakan.
\end{abstract}

Kata Kunci: Game Edukasi, Android, Hasil Belajar

\begin{abstract}
Learning media is a tool for teachers to convey information in learning activities. However, currently there are still many elementary schools that carry out learning activities using only media in the form of audio visuals, props, and objects around them so that students easily get bored participating in the learning activities. Technology enables teachers to create interesting learning media in the form of educational games based on android. The purpose of this study is to determine the level of validity according to experts' opinion regarding Android-based educational game products development to improve learning outcomes of fourth grade students. The type of this research is Research and Development $(R \& D)$. The research was carried out using the ASSURE development design model, namely Learner Analysis, Set Objectives, Select Method, Media \& Materials, Utizile Media \& Materials, Involve learners, and Evaluation and revision. The data obtained from the expert validation test were as follows: (1) the percentage obtained from the material expert validation test was $73 \%$ with the assessment criteria obtained was high; (2) the percentage obtained from the media expert validation test was $97 \%$ with the assessment criteria obtained was very high. Based on the validation test from media experts and material experts, it can be concluded that the learning media in the form of Android-Based Educational Games to Improve Learning Outcomes in Theme 7 in Grade IV Students is suitable to use.
\end{abstract}

Keywords: Educational Game, Android, Learning Outcomes

Copyright (c) 2021 Ririn Windawati, Henny Dewi Koeswanti

Corresponding author :

Email : 292017008@student.uksw.edu

DOI : https://doi.org/10.31004/basicedu.v5i2.835

ISSN 2580-3735 (Media Cetak)

ISSN 2580-1147 (Media Online)

Jurnal Basicedu Vol 5 No 2 Tahun 2021 p-ISSN 2580-3735 e-ISSN 2580-1147 
1028 Pengembangan Game Edukasi Berbasis Android untuk Meningkatkan Hasil Belajar Siswa di Sekolah Dasar - Ririn Windawati, Henny Dewi Koeswanti

DOI : https://doi.org/10.31004/basicedu.v5i2.835

\section{PENDAHULUAN}

Kurikulum adalah seperangkat rencana dan peraturan yang berisi tentang tujuan, isi, dan bahan pelajaran serta cara yang digunakan sebagai pedoman dalam kegiatan pembelajaran untuk mencapai tujuan pendidikan tertentu. Dalam kurikulum 2013, kegiatan pembelajaran menggunakan pembelajaran tematik. Karakteristik pembelajaran tematik yaitu dalam kegiatan pembelajaran berpusat pada siswa, sehingga guru hanya bertugas sebagai fasilitator saja yakni memfasilitasi kegiatan pembelajaran para siswa, memberikan kesempatan kepada siswa untuk bertanya dan menjawab pertanyaan siswa, memberikan ruang sepenuhnya kepada siswa agar bisa bebas berekspresi sesuai tema pelajaran, merangsang keingintahuan para siswa terhadap materi pelajaran yang disampaikan guru, memberikan kesempatan kepada siswa untuk mengomunikasikan pemahaman mereka. Sebagai fasilitator, apabila guru menemukan suatu kesalahan yang dilakukan siswa maka tugas guru yakni hanya perlu meluruskan dan menjelaskan. Karakteristik selanjutnya yaitu guru memberikan pengalaman langsung kepada siswa. Adapun yang dimaksud pengalaman langsung yaitu siswa mengalami dan mendalami materi secara langsung sehingga siswa dihadapkan pada pembelajaran konkret, tidak hanya memahami materi pelajaran melalui penjelasan dari guru atau dari buku-buku pelajaran saja. Dengan demikian kegiatan pembelajaran akan lebih bermakna. Karakteristik yang lainnya yaitu menggunakan prinsip belajar dengan bermain sehingga akan menciptakan suasana yang menyenangkan bagi siswa dan tentunya akan menarik antusias siswa untuk belajar. Keberhasilan pelaksanaan pembelajaran tematik dipengaruhi oleh rencana pelaksanaan pembelajaran yang telah dirancang dan diterapkan dalam kegiatan pembelajaran, sehingga guru harus dapat memilih media pembelajaran yang sesuai dengan karakteristik siswa agar dapat menarik minat dan motivasi siswa untuk belajar dengan antusias, senang dan semangat. Sejalan dengan (Ibnu, 2013:44) karakteristik yang harus ada dalam pembelajaran tematik yaitu kegiatan pembelajaran berpusat pada siswa, memberikan pengalaman langsung pada siswa, tidak terjadi pemisahan materi pelajaran secara jelas, bersifat fleksibel, hasil pembelajaran disesuaikan dengan minat dan kebutuhan siswa, menggunakan prinsip belajar sambil bermain dengan suasana yang menyenangkan, mengembangkan komunikasi siswa, dan menekankan proses daripada hasil.

Menurut Latuheru (dalam Nunuk Suryani \& Leo Agung, 2012:137) menyatakan bahwa media pembelajaran adalah bahan, alat, atau teknik yang digunakan dalam kegiatan pembelajaran yang berguna agar dalam proses interaksi komunikasi pendidikan antara guru dan siswa dapat berlangsung secara tepat guna dan berdaya guna. Sedangkan (Sanaky, 2013:45) mendefinisikan bahwa media pembelajaran adalah sebuah alat yang berfungsi untuk menyampaikan informasi tentang pembelajaran dalam kegiatan pembelajaran. Media pembelajaran memiliki manfaat seperti yang dikemukakan Sudjana dan Rivai (2011:2) bahwa manfaat media pembelajaran yaitu dapat membuat kegiatan pembelajaran menjadi lebih menarik dan menyenangkan sehingga akan menumbuhkan motivasi dan minat belajar pada diri siswa, memudahkan dalam menyampaikan materi sehingga akan mudah untuk dimengerti siswa, menjadikan metode pembelajaran lebih bervariasi, membuat siswa aktif sehingga tidak mudah bosan. Mengingat karakter siswa kelas IV pada dasarnya masih suka bermain sehingga dibutuhkan media pembelajaran yang menyenangkan seperti game edukasi berbasis android. Selain itu, siswa biasanya lebih suka bermain game yang diaplikasikan dalam sistem android.

Oleh karena itu, media pembelajaran yang disajikan dalam penelitian ini berupa game edukasi berbasis android yang diharapkan dmenarik minat dan antusias siswa dalam melakukan kegiatan pembelajaran. Pemilihan media pembelajaram yang sesuai dengan karakteristik siswa juga akan sangat berpengaruh besar terhadap keberhasilan kegiatan pembelajaran dibandingkan dengan tidak menggunakan media pembelajaran apapun sehingga dengan adanya media pembelajaran yang inovatif akan berguna untuk meningkatkan hasil belajar. Dengan demikian, penggunaan media pembelajaran berupa game edukasi berbasis android ini 
diharapkan dapat menarik minat dan antusias siswa untuk belajar sehingga dapat meningkatkan hasil belajar tema 7 pada siswa kelas IV.

Menurut (Marc Prensky, 2012:90) game edukasi adalah game yang dirancang khusus untuk kegiatan pembelajaran, tetapi bisa digunakan untuk bermain dan bersenang-senang. Sedangkan menurut (Dony Novaliendry, 2013:112) game edukasi adalah permainan yang telah dirancang khusus untuk mengajarkan siswa tentang suatu pembelajaran tertentu dalam mengembangkan konsep dan pemahaman, membimbing siswa dalam melatih kemampuan, serta memotivasi siswa untuk memainkannya. Game edukasi memiliki tujuan untuk menumbuhkan minat belajar siswa terhadap materi pembelajaran yang didalamnya terdapat suatu permainan sehingga dengan perasaan senang diharapkan siswa bisa lebih mudah untuk memahami materi pelajaran yang telah disampaikan guru dalam kegiatan pembelajaran. Selain itu, game edukasi juga memiliki manfaat untuk meningkatkan kemampuan berpikir kritis. Game edukasi ini merupakan game edukasi berbasis android sehingga akan lebih mudah untuk diakses dimana saja dan kapan saja karena mayoritas siswa kelas IV sudah dapat mengoperasikan android. Oleh karena itu, siswa dapat secara fleksibel dan praktis dalam mengakses game edukasi berbasis android tentang materi tema 7 khususnya subtema 1 pembelajaran 1 .

Adapun beberapa sumber penelitian tentang media pembelajaran berupa game edukasi yang dapat meningkatkan hasil belajar siswa diantaranya penelitian yang dilakukan oleh (Wulandari, Susilo, \& Kuswandi, 2017) yang mengemukakan bahwa dengan adanya media pembelajaran berupa multimedia interaktif bermuatan game edukasi dapat meningkatkan aktivitas dan hasil belajar siswa Sekolah Dasar. Peningkatan aktivitas belajar siswa mendapat perolehan persentase sebesar 85,05\% dengan katogeri sangat baik. Peningkatan aktivitas belajar siswa dapat terlihat dari setiap indikator yang dinilai pada saat kegiatan observasi berlangsung. Penelitian relevan selanjutnya dilakukan oleh (Firdaus \& Yermiandhoko, 2020) yang menunjukkan bahwa Game Edukasi "Petualangan Si Isaac" berbasis android yang di uji coba kelompok kecil atau terbatas pada 6 siswa kelas IV Sekolah Dasar, mendapatkan hasil sebesar 94,3\% dengan kategori sangat praktis dan nilai rata-rata siswa ketika sebelum menggunakan dan sesudah menggunakan media game edukasi "Petualangan Si Isaac" adalah 62,5 dan 79,3. Hal ini dapat disimpulkan bahwa media game edukasi "Petualangan Si Isaac" berbasis android dapat dikatakan valid dan sangat praktis untuk digunakan oleh siswa kelas IV Sekolah Dasar yang mengalami masalah kesulitan belajar pada materi gaya.

Berdasarkan hasil observasi dan wawancara yang telah dilakukan dengan guru kelas IV SD Negeri 1 Genengadal, maka di dapatkan informasi bahwa hasil belajar pada pembelajaran tematik khususnya pada kelas IV terbilang masih rendah karena disebabkan oleh beberapa faktor, salah satunya guru ketika melakukan kegiatan pembelajaran masih menggunakan metode ceramah sehingga membuat siswa mudah bosan. Kemudian guru belum menggunakan media pembelajaran yang bervariasi, selama ini hanya menggunakan media pembelajaran dalam bentuk audio visual, gambar dan benda-benda disekitar saja. Dalam hal ini, guru juga belum memanfaatkan teknologi secara maksimal. Hal ini juga akan membuat siswa mudah bosan mengikuti kegiatan pembelajaran sehingga akan berdampak terhadap hasil belajar pada pembelajaran tematik. Sehingga dapat dikatakan bahwa kegiatan pembelajaran yang dilakukan guru belum optimal.

Berdasarkan penelitian yang telah dilakukan sebelumnya, dapat dijadikan bahan sebagai dasar acuan untuk mengembangkan media pembelajaran berupa Game Edukasi Berbasis Android Untuk Meningkatkan Hasil Belajar Tema 7 Pada Siswa Kelas IV. Dalam pengembangan game edukasi berbasis android, hanya berfokus pada tema 7 subtema 1 pembelajaran ke 1 kelas IV muatan pelajaran Bahasa Indonesia dan IPA. Pengembangan media pembelajaran berupa game edukasi berbasis android ini memberikan beberapa kelebihan yakni game edukasi berbasis android ini dikemas dalam bentuk permainan yang dipasang di android agar lebih mudah dan praktis dalam menggunakannya karena dapat diakses dimana saja dan kapan saja. Oleh karena itu, untuk mengatasi masalah diatas maka akan dikembangkan produk media pembelajaran 
1030 Pengembangan Game Edukasi Berbasis Android untuk Meningkatkan Hasil Belajar Siswa di Sekolah Dasar - Ririn Windawati, Henny Dewi Koeswanti

DOI : https://doi.org/10.31004/basicedu.v5i2.835

berupa game edukasi berbasis android ini dengan judul penelitian "Pengembangan Game Edukasi Berbasis Android Untuk Meningkatkan Hasil Belajar Tema 7 Pada Siswa Kelas IV”.

\section{METODE}

Penelitian dan pengembangan media pembelajaran berupa Game Edukasi Berbasis Android Untuk Meningkatkan Hasil Belajar Tema 7 Pada Siswa Kelas IV telah dilaksanakan menggunakan metode Research and Development atau $(R \& D)$ yang dikembangkan oleh Sukmadinata (2016:164) yang terdiri atas 3 tahap yaitu 1)Studi pendahuluan, 2)Pengembangan produk, 3)Pengujian. Penelitian dilaksanakan dengan menggunakan model desain pengembangan ASSURE yang terdiri 6 tahap yaitu Analisis Siswa (Analisis Learner), Menetapkan Tujuan (State Objektive), Memilih metode, media dan Materials (Select Method, Media \& Materials), Memanfaatkan Media dan Bahan ajar (Utizile media \& Materials), Melibatkan siswa dalam kegiatan pembelajaran (Require Learner),dan Evaluasi dan revisi (Evaluasi \& Revise) (Heinich, R., Molenda, M., \& Russel, 1993:34-35). Namun hanya dilaksanakan sampai tahap memanfaatkan media dan bahan ajar (Utizile media \& Materials) saja karena kegiatan pembelajaran pada siswa Sekolah Dasar masih dilaksanakan secara jarak jauh/daring. Penelitian ini bertujuan untuk mengembangkan media pembelajaran berupa Game Edukasi Berbasis Android Untuk Meningkatkan Hasil Belajar Tema 7 Pada Siswa Kelas IV dan bertujuan untuk mengetahui tingkat validitas dari ahli materi dan ahli media mengenai produk pengembangan media pembelajaran berupa Game Edukasi Berbasis Android Untuk Meningkatkan Hasil Belajar Tema 7 Pada Siswa Kelas IV. Pada tahap validasi digunakan untuk menilai media pembelajaran berupa game edukasi berbasis android yang telah dikembangkan. Data tersebut diperoleh dari ahli media dan ahli materi dan dianalisis menggunakan teknik deskriptif presentase dan kategori yang berguna untuk menggambarkan kelayakan uji coba produk media pembelajaran berupa game edukasi berbasis android. Skor hasil validasi materi dan validasi media dipresentasekan menggunakan rumus :

$$
\mathrm{AP}=\frac{\text { skor aktwal }}{\text { skorideal }} \times 100 \%=
$$

AP : Angka Presentase

Skor Aktual : Skor yang diberikan oleh validator atau ahli

Skor Ideal : Skor maksimal hasil kali jumlah item dengan skor maksimal dari masing-masing item

Angka presentasi yang diperoleh selanjutnya dikelompokkan kedalam kriteria penilaian tabel 1.

Tabel 1

\section{Kategori Uji Validasi Ahli}

\begin{tabular}{|l|l|}
\hline \multicolumn{1}{|c|}{ Skor } & \multicolumn{1}{c|}{ Kriteria } \\
\hline $81-100 \%$ & Sangat Tinggi \\
\hline $61-80 \%$ & Tinggi \\
\hline $41-60 \%$ & Cukup \\
\hline $21-40 \%$ & Rendah \\
\hline $1-20 \%$ & Sangat Rendah \\
\hline
\end{tabular}

Hasil dari uji validasi materi dan validasi media dari produk berupa Game Edukasi Berbasis Android Untuk Meningkatkan Hasil Belajar Tema 7 Pada Siswa Kelas IV dapat dikatakan layak untuk diuji cobakan 
1031 Pengembangan Game Edukasi Berbasis Android untuk Meningkatkan Hasil Belajar Siswa di Sekolah Dasar - Ririn Windawati, Henny Dewi Koeswanti

DOI : https://doi.org/10.31004/basicedu.v5i2.835

jika presentase minimal mencapai kategori tinggi yaitu $\geq 61 \%$ ((Mawardi, 2014:113). Hasil uji coba akan diperbaiki sesuai saran yang diberikan oleh ahli materi dan ahli media namun tidak diuji cobakan ke siswa kelas IV Sekolah Dasar karena kegiatan pembelajaran masih dilaksanakan secara jarak jauh/daring.

\section{HASIL PENELITIAN DAN PEMBAHASAN}

Penelitian penggembangan media pembelajaran berupa Game Edukasi Berbasis Android Untuk Meningkatkan Hasil Belajar Tema 7 Pada Siswa Kelas IV menggunakan langkah-langkah pengembangan menurut sukmadinata. Langkah pertama yaitu studi pendahuluan yang dilaksanakan sebagai langkah awal untuk mengembangkan media pembelajaran berupa Game Edukasi Berbasis Android untuk Meningkatkan Hasil Belajar Tema 7 Pada Siswa Kelas IV. Dalam studi pendahuluan dilakukan tiga tahap yakni studi pustaka, survei lapangan, dan penyusunan draft produk awal. Berdasarkan hasil wawancara dengan guru kelas IV SD Negeri 1 Genengadal, media pembelajaran yang digunakan oleh guru saat melaksanakan kegiatan pembelajaran yakni hanya menggunakan media dalam bentuk audio visual, alat peraga, dan benda-benda di sekitar saja sehingga membuat siswa mudah bosan dan guru belum memanfaatkan secara maksimal teknologi.

Langkah kedua yaitu penelitian dilakukan dengan model desain pengembangan ASSURE menurut Heinich, Molenda, Russel (1993: 34-35) dilakukan dengan enam tahap yang terdiri dari Analyze Learner, State Objective, Select Method, Media or Materials, Utilizee Media and Materials,Require Learned, Participation, dan Evaluate and Revise. Namun hanya dilaksanakan sampai tahap memanfaatkan media dan bahan ajar (Utizile media \& Materials) saja karena kegiatan pembelajaran pada siswa Sekolah Dasar masih dilaksanakan secara jarak jauh/daring. Pada tahap pertama Analyze Learners (Analisis Karakter Siswa) didapatkan data berdasarkan hasil wawancara dari guru kelas IV SD Negeri 1 Genengadal, siswa kelas IV mudah bosan saat kegiatan pembelajaran berlangsung, dibuktikan dengan rendahnya hasil belajar tematik. Hal ini terjadi karena guru hanya menggunakan metode ceramh dan hanya menggunakan media pembelajaran dalam bentuk audio visual, alat peraga, dan benda-benda di sekitar saja sehingga kurang menarik antusias siswa dalam pembelajaran. Sesuai dengan karakter siswa kelas IV yang masih suka bermain, pembelajaran menggunakan media game edukasi berbasis android akan lebih menarik antusias siswa karena bisa belajar sambil bermain.

Pada tahap kedua State Objectives (Menetapkan Tujuan Pembelajaran) yakni merumuskan atau menetapkan tujuan pembelajaran pada penelitian ini termasuk tahap kedua dalam model desain pengembangan ASSURE. Namun, sebelum menetapkan tujuan pembelajaran akan menetapkan kompetensi dasar dan indikator pencapaian kompetensi pembelajaran terlebih dahulu.

Tabel 2

Kompetensi Dasar dan Indikator

\begin{tabular}{|c|c|c|}
\hline Muatan Pelajaran & Kompetensi Dasar & Indikator \\
\hline \multirow[t]{3}{*}{ Bahasa Indonesia } & \multirow[t]{3}{*}{$\begin{array}{l}\text { 3.7 Menggali pengetahuan baru yang } \\
\text { terdapat pada teks }\end{array}$} & $\begin{array}{l}\text { 3.7.1 Menemukan kata sulit dan } \\
\text { artinya yang terdapat pada teks } \\
\text { bacaan suku bangsa di indonesia }\end{array}$ \\
\hline & & 3.7.2 Menjelaskan pokok pikiran \\
\hline & & $\begin{array}{l}\text { 3.7.3 Menentukan cara mencari } \\
\text { pokok pikiran }\end{array}$ \\
\hline
\end{tabular}


1032 Pengembangan Game Edukasi Berbasis Android untuk Meningkatkan Hasil Belajar Siswa di Sekolah Dasar - Ririn Windawati, Henny Dewi Koeswanti

DOI : https://doi.org/10.31004/basicedu.v5i2.835

\begin{tabular}{|c|c|c|}
\hline & $\begin{array}{l}\text { 4.7 Menyampaikan pengetahuan baru } \\
\text { dari teks nonfiksi ke dalam tulisan } \\
\text { dengan bahasa sendiri }\end{array}$ & $\begin{array}{l}\text { 4.7.1 Menuliskan kata sulit yang } \\
\text { terdapat di teks bacaan suku bangsa } \\
\text { di indonesia dan menuliskan artinya } \\
\text { menggunakan bahasa sendiri }\end{array}$ \\
\hline & & $\begin{array}{l}\text { 4.7.2 Menuliskan pokok pikiran } \\
\text { yang terdapat pada teks bacaan } \\
\text { suku bangsa di Indonesia } \\
\text { menggunakan bahasa sendiri }\end{array}$ \\
\hline IPA & $\begin{array}{l}\text { 3.3 Mengidentifikasi macam-macam } \\
\text { gaya, antara lain: gaya otot, gaya }\end{array}$ & 3.3.1 Menjelaskan pengertian gaya. \\
\hline & dan gaya gesekan & $\begin{array}{l}\text { 3.3.2Mengidentifikasi macam- } \\
\text { macam gaya, antara lain: gaya otot, } \\
\text { gaya listrik, gaya magnet, gaya } \\
\text { gravitasi, dan gaya gesekan. }\end{array}$ \\
\hline & & $\begin{array}{l}\text { 3.3.3 Mengidentifikasi gaya otot } \\
\text { berdasarkan pengaruhnya }\end{array}$ \\
\hline & $\begin{array}{l}\text { 4.3 Mendemonstrasikan manfaat gaya } \\
\text { dalam kehidupan sehari-hari,misalnya }\end{array}$ & $\begin{array}{l}\text { 4.3.1 Melakukan gaya otot dalam } \\
\text { kehidupan sehari-hari }\end{array}$ \\
\hline & gaya gravitasi, dan gaya gesekan & $\begin{array}{l}\text { 4.3.2 Menuliskan hasil dari } \\
\text { melakukan gaya otot }\end{array}$ \\
\hline
\end{tabular}

Setelah menentukan rumusan indikator dari kompetensi dasar yaitu menentukan tujuan pembelajaran, adapun rumusan tujuan pembelajaran dari muatan pelajaran Bahasa Indonesia dan IPA yaitu sebagai berikut : 1)Dengan menyimak video pembelajaran yang terdapat di game edukasi berbasis android, siswa dapat menemukan kata sulit dan artinya yang terdapat pada teks bacaan "Suku Bangsa di Indonesia". 2) Dengan bermain game edukasi berbasis android, siswa dapat menjelaskan pokok pikiran. 3)Dengan bermain game edukasi berbasis android, siswa dapat menentukan cara mencari pokok pikiran. 4)Dengan menyimak video pembelajaran yang terdapat di game edukasi berbasis android, siswa dapat menuliskan kata sulit yang terdapat di teks bacaan "Suku Bangsa di Indonesia" dan menuliskan artinya menggunakan bahasa sendiri. 5) Dengan menyimak video pembelajaran yang terdapat di game edukasi berbasis android, siswa dapat menuliskan pokok pikiran yang terdapat pada teks bacaan "Suku Bangsa di Indonesia" menggunakan bahasa sendiri. 6) Dengan menyimak video pembelajaran yang terdapat di game edukasi berbasis android, siswa dapat menjelaskan pengertian gaya. 7)Dengan menyimak video pembelajaran yang terdapat di game edukasi berbasis android, siswa dapat mengidentifikasi macam-macam gaya, antara lain: gaya otot, gaya listrik, gaya magnet, gaya gravitasi, dan gaya gesekan. 8)Dengan bermain game edukasi berbasis android, siswa dapat mengidentifikasi gaya otot berdasarkan pengaruhnya. 9)Dengan menyimak video pembelajaran yang terdapat di game edukasi berbasis android, siswa dapat melakukan gaya otot dalam kehidupan sehari-hari. 10)Dengan menyimak video pembelajaran yang terdapat di game edukasi, siswa dapat menuliskan hasil dari melakukan gaya otot. 
1033 Pengembangan Game Edukasi Berbasis Android untuk Meningkatkan Hasil Belajar Siswa di Sekolah Dasar - Ririn Windawati, Henny Dewi Koeswanti

DOI : https://doi.org/10.31004/basicedu.v5i2.835

Pada tahap ketiga, Select Method, Media or Materials (Memilih Metode, Media, atau Bahan Ajar) yaitu setelah menemukan indikator kompetensi dasar dan tujuan pembelajaran yaitu memilih metode, media, atau bahan ajar yang digunakan. Metode yang digunakan untuk pembelajaran daring yakni game based learning karena metode game based learning adalah metode pembelajaran yang menggunakan aplikasi permainan/game yang dirancang untuk pembelajaran atau untuk tujuan pembelajaran (Prasetya, dkk, 2013). Selanjutnya, media yang akan digunakan dalam pembelajaran tema 7 subtema 1 pembelajaran 1 muatan pelajaran Bahasa Indonesia dan Ilmu Pengetahuan Alam yaitu game edukasi berbasis android.

Pada tahap ke empat, Utilize Media or Materials (Memanfaatkan Media atau Bahan Ajar) yaitu media pembelajaran berupa game edukasi berbasis android dilakukan uji validitas ahli dari ahli materi dan ahli media guna mengetahui kelayakan dari media pembelajaran berupa Game Edukasi Berbasis Android Untuk Meningkatkan Hasil Belajar Tema 7 Pada Siswa Kelas IV. Validasi materi pada media pembelajaran berupa Game Edukasi Berbasis Android Untuk Meningkatkan Hasil Belajar Tema 7 Pada Siswa Kelas IV dilakukan oleh dosen Program Studi Pendidikan Guru Sekolah Dasar, Fakultas Keguruan dan Ilmu Pendidikan, Universitas Kristen Satya Wacana, yaitu Dr. Mawardi, M.Pd. Validasi materi dilakukan dengan memberikan rubrik instrumen uji validasi materi yang terdapat 3 aspek menurut (Akbar, 2013:39) yakni aspek relevansi, keakuratan, sistematika sajian. Pada aspek relevansi terdapat 6 indikator yaitu kesesuaian materi dengan kurikulum Sekolah Dasar, kesesuaian judul dengan materi pembelajaran, kesesuaian kompetensi dasar dengan materi pembelajaran, kesesuaian ilustrasi dengan tahap perkembangan siswa, soal/kuis relevan dengan materi pembelajaran, kesesuaian gambar, video, dan audio untuk memperjelas materi pembelajaran. Kemudian pada aspek keakuratan terdapat 2 indikator yakni kesesuaian materi dengan keilmuan dan kedalaman materi pembelajaran sesuai dengan tingkat perkembangan siswa. Selanjutnya pada aspek sistematika sajian terdapat 4 indikator yaitu uraian materi sesuai dengan pembelajaran tematik, keruntutan susunan materi pembelajaran, kelengkapan materi pembelajaran, kejelasan bahasa yang digunakan. Jadi, terdapat 12 indikator dari 3 aspek dengan skor maksimal 5 dan skor minimal 1 dari masing-masing indikator.

Tabel 3

Hasil Data Validasi Materi

\begin{tabular}{|l|c|c|}
\hline \multicolumn{1}{|c|}{ Aspek } & Skor ideal & Skor aktual \\
\hline 1. Relevansi & 30 & 21 \\
\hline 2. Keakuratan & 10 & 8 \\
\hline 3. Sistematika sajian & 20 & 15 \\
\hline Total skor & 60 & 44 \\
\hline
\end{tabular}

$$
\begin{aligned}
& \mathrm{AP}=\frac{\text { skor aktwal }}{\text { skorideal }} \times 100 \%= \\
& \mathrm{AP}=\frac{44}{60} \times 100 \%=73 \%
\end{aligned}
$$

Penilaian yang diberikan oleh validator materi memperoleh presentase sebesar $73 \%$ yang menunjukkan kriteria penilaian tinggi. Validator materi menilai produk media game edukasi berdasarkan 3 aspek dari 12 indikator yakni aspek relevansi, aspek keakuratan dan aspek sistematika sajian. Penggunaan media pembelajaran berupa game edukasi berbasis android bertujuan untuk membantu siswa dalam memahami materi tema 7, subtema 1, pembelajaran 1. Game edukasi berbasis android berisi soal-soal kuis 
1034 Pengembangan Game Edukasi Berbasis Android untuk Meningkatkan Hasil Belajar Siswa di Sekolah Dasar - Ririn Windawati, Henny Dewi Koeswanti

DOI : https://doi.org/10.31004/basicedu.v5i2.835

muatan pelajaran Bahasa Indonesia dan IPA. Dengan begitu siswa dapat berlatih soal-soal kuis namun juga bisa bermain.

Selanjutnya, validasi media pada media pembelajaran berupa Game Edukasi Berbasis Android Untuk Meningkatkan Hasil Belajar Tema 7 Pada Siswa Kelas IV dilakukan oleh dosen Sistem Informatika, Fakultas Teknologi dan Informatika, Universitas Kristen Satya Wacana, yaitu Deasy Carolina, S.E.,M.M. Validasi media dilakukan dengan memberikan rubrik instrumen uji validasi media yang terdapat 4 aspek dari 12 indikator dengan skor maksimal 5 dan skor minimal 1 dari masing-masing indikator. Adapun 4 aspek uji validasi media yakni aspek tampilan, aspek interaksi, aspek kontrol dan aspek bentuk. Pada aspek tampilan terdapat 4 indikator yaitu kesesuaian media game edukasi terhadap konten materi pembelajaran, kesesuaian pemilihan tampilan background pada game edukasi, kesesuaian penggunaan gambar, audio, video atau foto dengan konten materi, kesesuaian teks. Kemudian pada aspek interaksi terdapat 2 indikator yaitu tersedianya fasilitas dan kesesuaian materi dengan topik. Selanjutnya pada aspek kontrol terdapat 3 indikator yaitu kemudahan penggunaan media game edukasi, kemudahan akses materi, kemudahan akses tombol fitur. Aspek terakhir yakni aspek bentuk memiliki 3 indikator yaitu kesesuaian animasi, kemudahan virtual classroom, media game edukasi dapat digunakan sebagai sumber belajar. Data hasil validasi ahli media disajikan dalam tabel 4. berikut :

Tabel 4

Data Hasil Validasi Ahli Media

\begin{tabular}{|l|c|c|}
\hline \multicolumn{1}{|c|}{ Aspek } & Skor ideal & Skor aktual \\
\hline 1. Tampilan & 20 & 20 \\
\hline 2. Interaksi & 10 & 10 \\
\hline 3. Kontrol & 15 & 14 \\
\hline 4. Bentuk & 15 & 14 \\
\hline Total skor & 60 & 58 \\
\hline
\end{tabular}

$$
\begin{aligned}
& \mathrm{AP}=\frac{\text { skor aktual }}{\text { skorideal }} \times 100 \%= \\
& \mathrm{AP}=\frac{58}{60} \times 100 \%=97 \%
\end{aligned}
$$

Penilaian yang diberikan oleh validator media memperoleh presentase sebesar 97\% yang menunjukkan kriteria penilaian sangat tinggi. Validator media menilai produk media game edukasi berbasis android berdasarkan 4 aspek dari 12 indikator yaitu aspek tampilan, aspek interaksi, aspek kontrol, dan aspek bentuk. Media pembelajaran berupa game edukasi berbasis android sesuai dengan perkembangan siswa kelas IV SD dan mudah untuk digunakan. Media pembelajaran ini disusun menjadi media pembelajaran yang menarik antusias dan minat belajar siswa kelas IV SD, sehingga siswa akan lebih termotivasi dan bersemangat dalam belajar materi tema 7, subtema 1, pembelajaran 1. Pada tahap Require Learner Participation (Melibatkan Siswa dalam Pembelajaran) dan Evaluate and Revise (Evaluasi dan Revisi) tidak dapat dilaksanakan karena kegiatan pembelajaran pada siswa Sekolah Dasar masih dilaksanakan secara jarak jauh/daring sehingga hanya bisa dilaksanakan sampai tahap Utilizee Media and Materials saja. 
Langkah terakhir yaitu pengujian yang seharusnya dilaksanakan di Sekolah Dasar dengan memberikan pre test dan post test kepada siswa kelas IV. Kegiatan pre test dilakukan sebelum produk berupa game edukasi berbasis android diberikan kepada siswa kelas IV. Sedangkan kegiatan post test dilakukan setelah produk berupa game edukasi berbasis android diberikan kepada siswa. Namun karena adanya covid-19 yang mengharuskan kegiatan pembelajaran siswa Sekolah Dasar dilaksanakan secara jarak jauh/daring sehingga langkah ketiga yaitu pengujian tidak bisa dilaksanakan pada siswa kelas IV Sekolah Dasar.

Spesifikasi produk media pembelajaran berupa Game Edukasi Berbasis Android Untuk Meningkatkan Hasil Belajar Tema 7 Pada Siswa Kelas IV sebagai berikut :

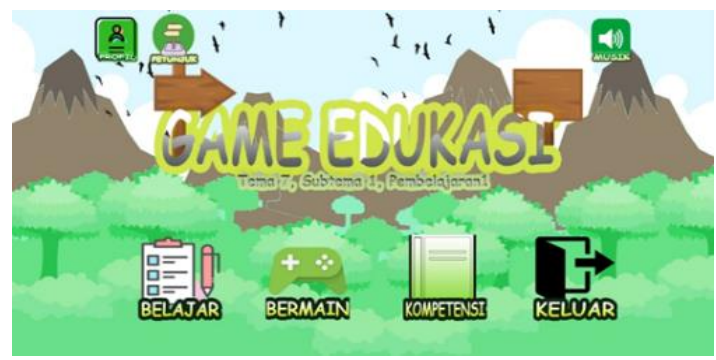

Gambar 1. Menu Home

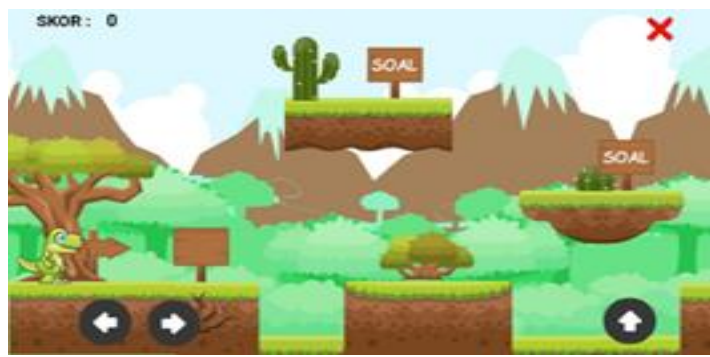

Gambar 3. Tampilan Bermain

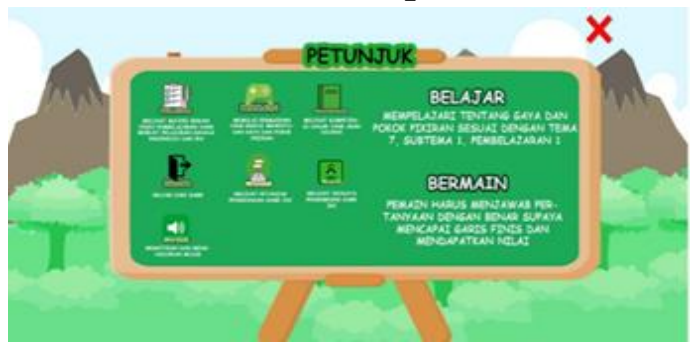

Gambar 5. Tampilan Petunjuk

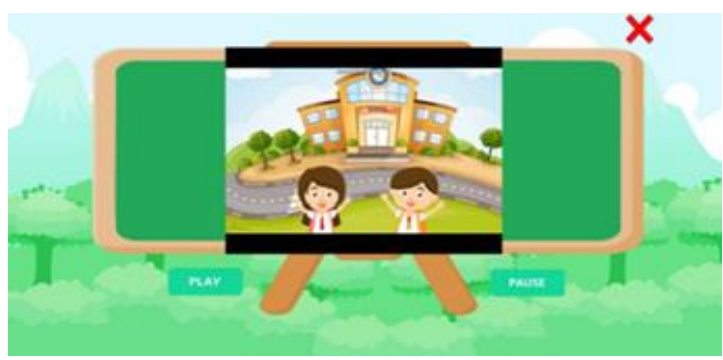

Gambar 2. Tampilan Belajar

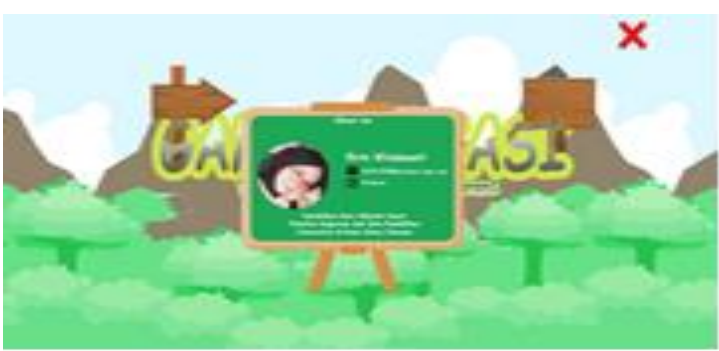

Gambar 4. Tampilan Profil

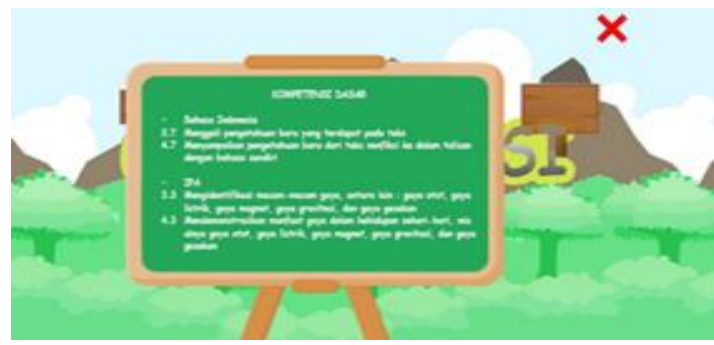

Gambar 6. Tampilan Kompetensi

Pada tahap revisi dilakukan setelah melakukan uji validitas dan mendapatkan validasi dari ahli materi dan ahli media. Revisi dilakukan apabila mendapatkan saran dari ahli. Saran yang terdapat di lembar uji instrumen validasi dijadikan pedoman untuk dilakukan perbaikan media game edukasi berbasis android. Revisi hanya dilakukan sesuai saran yang diberikan ahli materi saja, karena ahli media tidak memberikan saran pada lembar instrumen uji validasi media. Adapun saran dari ahli materi yakni tambahkan materi mengakomodir semua indikator dan tambahkan materi singkat agar lebih komprehensif pemahaman siswa.

Berikut ini gambar hasil perbaikan sesuai saran dari ahli materi : 


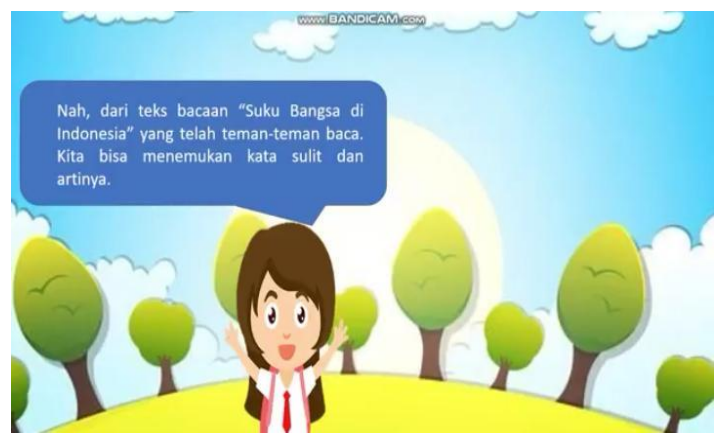

Gambar 7. Menemukan kata sulit

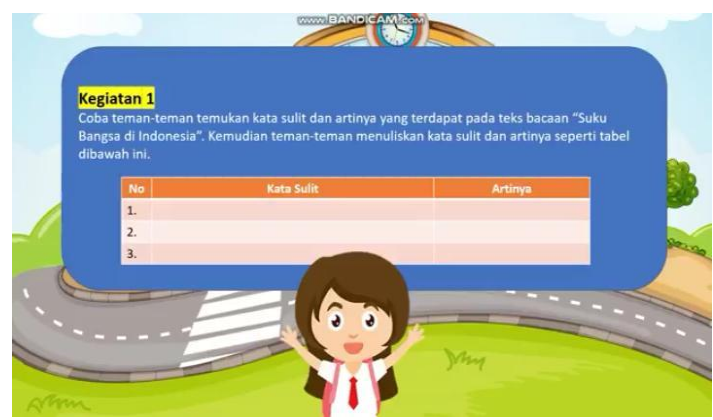

Gambar 9. Kegiatan 1

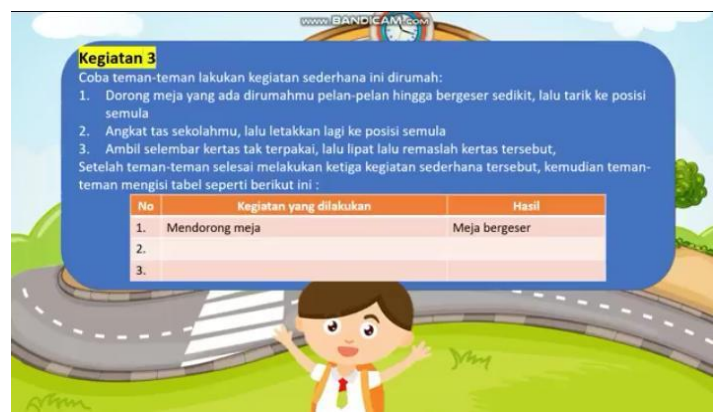

Gambar 11. Kegiatan 3

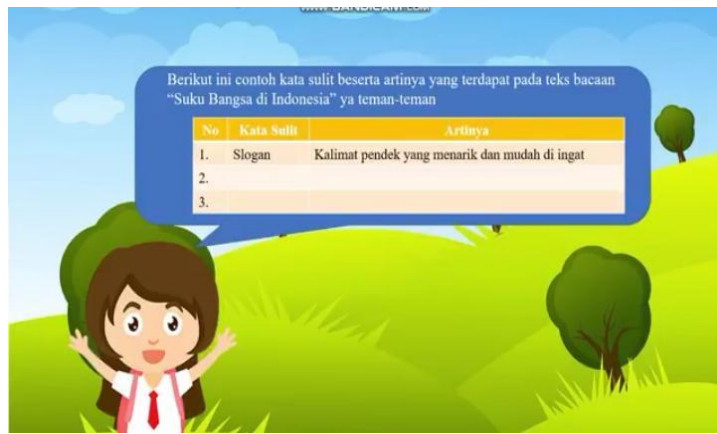

Gambar 8. Kata sulit dan artinya

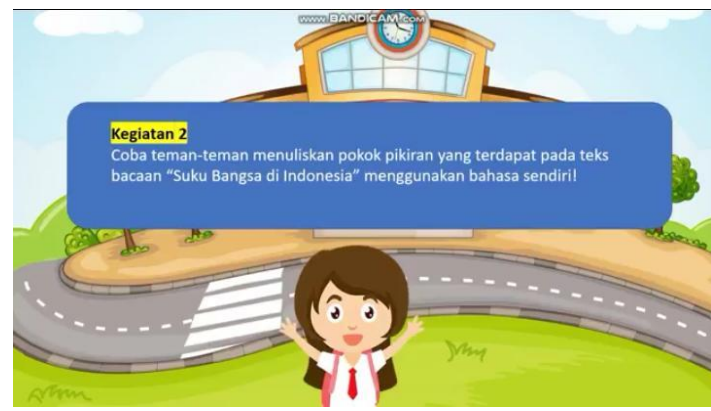

Gambar 10. Kegiatan 2

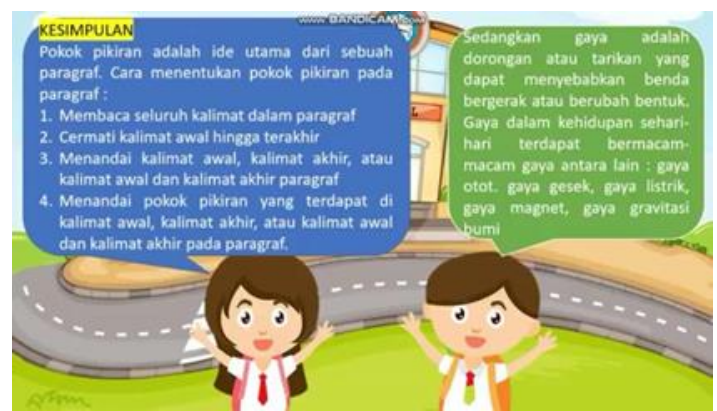

Gambar 12. Materi singkat

Presentase yang didapat dari validasi ahli materi sebesar $73 \%$ termasuk dalam kategori tinggi dan presentase yang didapat dari validasi ahli media sebesar $97 \%$ termasuk dalam kategori sangat tinggi. Media game edukasi berbasis android dapat membantu siswa dalam memahami tema 7, subtema 1, pembelajaran 1 muatan pelajaran Bahasa Indonesia dan IPA dalam sebuah permainan. Penggunaan game edukasi berbasis android dapat memberikan pengalaman baru untuk siswa dalam belajar karena dapat dilakukan dimana saja dan kapan saja dengan bantuan smartphone android sehingga dapat meningkatkan antusias belajar dan dapat meningkatkan hasil belajar tema 7 pada siswa kelas IV. Selain itu, media game edukasi berbasis android dapat dijadikan sebagai salah satu referensi untuk guru dalam penggunaan media pembelajaran tema 7 , subtema 1 , pembelajaran 1 dan dapat juga dijadikan sebagai sumber belajar dalam kegiatan pembelajaran.

Penelitian yang dilakukan oleh (ASRI \& YERMIANDHOKO, 2018:419) bahwa game edukasi "si galang" berbasis android memperoleh rata-rata penilaian sebanyak $75 \%$ dari validasi materi dan mendapatkan rata-rata penilaian sebanyak $82,5 \%$ dari validasi media. Dari hasil uji coba terbatas, didapatkan rata-rata penilaian sebesar $87 \%$. Sedangkan dari hasil uji coba luas, didapatkan rata-rata penilaian sebesar 91\%. Maka, hasil rata-rata post-test siswa yaitu 82,5 dan berada diatas KKM sekolah. Berdasarkan data yang telah 
1037 Pengembangan Game Edukasi Berbasis Android untuk Meningkatkan Hasil Belajar Siswa di Sekolah Dasar - Ririn Windawati, Henny Dewi Koeswanti

DOI : https://doi.org/10.31004/basicedu.v5i2.835

diperoleh, maka dapat disimpulkan bahwa game edukasi "Si Galang" layak untuk digunakan sebagai media pembelajaran alternatif dan mampu memberikan hasil belajar siswa diatas KKM sekolah. Penelitian relevan selanjutnya dilakukan oleh Penelitian yang dilakukan oleh (QURROTUL UYUN \& ZUHDI, 2019:3238) bahwa game edukasi "Al Qur"an Ratsel Bambini” berbasis android memperoleh persentase 100\% dengan kategori sangat layak dari ahli materi, sedangkan dari ahli media mendapat persentase $84,61 \%$ dengan kategori sangat layak. Adapun penilaian kelayakan melalui respon siswa memperoleh persentase sebesar 91,60\% dengan kategori sangat layak. Sedangkan hasil uji coba, mendapatkan rata-rata perolehan nilai pretest siswa sebesar 69,53 dan rata-rata perolehan nilai posttest siswa adalah 79,61. Maka dapat disimpukan bahwa game edukasi “Al Qur"an Ratsel Bambini” efektif untuk meningkatkan hasil belajar.

Media pembelajaran berupa Game Edukasi Berbasis Android Untuk Meningkatkan Hasil Belajar Tema 7 Pada Siswa Kelas IV memiliki keterbatasan yakni hanya dapat digunakan di smartphone android saja, hanya berfokus pada tema 7 subtema 1 pembelajaran 1 muatan pelajaran Bahasa Indonesia dan Ilmu Pengetahuan Alam saja. Kemudian membutuhkan kuota data yang cukup besar untuk menginstal aplikasi game edukasi berbasis android.

\section{KESIMPULAN}

Penelitian dan pengembangan media pembelajaran berupa Game Edukasi Berbasis Android Untuk Meningkatkan Hasil Belajar Tema 7 Pada Siswa Kelas IV telah dilaksanakan menggunakan metode Research and Development atau $(R \& D)$ yang dikembangkan oleh Sukmadinata yang terdiri atas 3 tahap yaitu 1)Studi pendahuluan, 2)Pengembangan produk, 3)Pengujian. Penelitian dilaksanakan menggunakan model ASSURE dalam pengembangan media pembelajaran berupa Game Edukasi Berbasis Android Untuk Meningkatkan Hasil Belajar Pada Siswa Kelas IV dilakukan dengan enam tahap yang terdiri dari Analyze Learner, State Objective, Select Method, Media or Materials, Utilizee Media and Materials, Require Learned Participation, dan Evaluate and Revise. Namun pada tahap Require Learned Participation, dan Evaluate and Revise tidak dilaksanakan karena kegiatan pembelajaran pada siswa Sekolah Dasar masih dilaksanakan secara jarak jauh/daring sehingga hanya bisa dilaksanakan sampai tahap Utilizee Media and Materials saja.

Media pembelajaran berupa Game Edukasi Berbasis Android Untuk Meningkatkan Hasil Belajar Siswa Kelas IV telah melalui uji validitas dari ahli materi dan ahli media. Persentase yang diperoleh dari uji validasi ahli materi adalah $73 \%$ dengan kriteria penilaian yang didapatkan adalah tinggi dan presentase yang diperoleh dari uji validasi ahli media adalah 97\% dengan kriteria penilaian yang didapatkan adalah sangat tinggi. Berdasarkan uji validasi dari ahli media dan ahli materi, maka dapat disimpulkan bahwa media pembelajaran berupa Game Edukasi Berbasis Android Untuk Meningkatkan Hasil Belajar Tema 7 Pada Siswa Kelas IV dapat dikatakan layak digunakan.

\section{DAFTAR PUSTAKA}

Akbar, S. (2013). Instrumen perangkat pembelajaran. Bandung: Rosda Karya.

ASRI, D., \& YERMIANDHOKO, Y. (2018). Pengembangan Game Edukasi Si Galang Berbasis Android Pada Mata Pelajaran Ips Materi Pakaian Adat Untuk Kelas IV Sd. Jurnal Penelitian Pendidikan Guru Sekolah Dasar, 6(3), 254964.

Firdaus, Y. A., \& Yermiandhoko, Y. (2020). PENGEMBANGAN MEDIA GAME EDUKASI “ PETUALANGAN SI ISAAC " BERBASIS ANDROID PADA MATERI GAYA KELAS IV SEKOLAH DASAR Abstrak. Jpgsd, 08(2), 240-249. 
1038 Pengembangan Game Edukasi Berbasis Android untuk Meningkatkan Hasil Belajar Siswa di Sekolah Dasar - Ririn Windawati, Henny Dewi Koeswanti

DOI : https://doi.org/10.31004/basicedu.v5i2.835

Heinich, R., Molenda, M., \& Russel, J. (1993). Instructional media and the new tec. instruction. New York: John Wiley and Sons.

Ibnu, H. (2013). Panduan Lengkap Kurikulum Tematik Untuk SD/MI. Yogyakarta: DIVA Press.

Suryani, Nunuk \& Leo Agung. (2011). Strategi Belajar Mengajar. Yogyakarta: Ombak.

Marc, P. (2012). From Digital Natives to Digital Wisdom. New York: Purwoko,Bangkit.

Mawardi. (2014). Model Desain Pembelajaran Konsep Dasar PKn Berbasis Belajar Mandiri Menggunakan Moodle. Salatiga: Widya Sari Press Salatiga.

Novaliendry, D. (2013). Aplikasi Game Geografi Berbasis Multimedia Interaktif (Studi Kasus Siswa Kelas IX SMP N 1 RAO). Jurnal Teknologi Informasi \& Pendidikan.

Prasetya. (2013). Digital Game Based Learning Untuk Anak Usia Dini. TEKNO.

QURROTUL UYUN, L., \& ZUHDI, U. (2019). Pengembangan Game Edukasi “Al Qur'an Ratsel Bambini” Berbasis Android Mata Pelajaran Pai Materi Hafalan Surat Pendek Kelas V Sekolah Dasar. Jurnal Penelitian Pendidikan Guru Sekolah Dasar, 7(4), 3228-3238.

Rivai, S. dan. (2011). Sudjana dan Rivai. Media Pengajaran. Bandung: Sinar Baru Algensindo.

Sanaky. (2013). Media Pembelajaran Interaktif-Inovatif. Yogyakarta: Kaukaban Dipantara.

Sukmadinata, N. S. (2016). Metode Penelitian Pendidikan. Bandung: Remaja Rosda Karya.

Wulandari, R., Susilo, H., \& Kuswandi, D. (2017). Penggunaan Multimedia Interaktif Bermuatan Game Edukasi Untuk Siswa Sekolah Dasar. Pendidikan, 2(8), 1024-1029. 